The Effectiveness of Constructivist Learning with Learning Cycle Model Against Activities and Achievement of KKM English Subjects Class XI ATPH Students of SMK Negeri 1 Woja

\title{
Efektivitas Pembelajaran Konstruktivis dengan Model Siklus Belajar Terhadap Aktivitas dan Ketercapaian KKM Mata Pelajaran Bahasa Inggris Siswa Kelas XI ATPH SMK Negeri 1 Woja
}

\section{Nurdewiyati ${ }^{1}$}

email: nurdewiyati12311@gmail.com

\begin{abstract}
The purpose of this study was to determine the effectiveness of constructivist learning with a learning cycle model of student activities in English subjects for class XI students of ATPH SMK Negeri 1 Woja in the academic year 2018/2019. The method used in this research is descriptive qualitative. The research subjects were students of class XI ATPH SMK Negeri 1 Woja in the 2018/2019 school year. Data used are the results of test results, and interviews. The results showed that the brainstorming activity could improve students' skills in using acceptable spoken English specifically to express descriptive monologues. Evidence from quantitative data analysis shows that the value of student learning outcomes, in general, is above the English Minimum Mastery Criteria (KKM) of 70.
\end{abstract}

\begin{abstract}
Abstrak: Tujuan penelitian ini adalah Untuk mengetahui efektifitas pembelajaran konstruktivis dengan model siklus belajar terhadap aktifitas siswa pada mata pelajaran Bahasa Inggris siswa kelas XI ATPH SMK Negeri 1 Woja tahun pelajaran 2018/2019. Metode yang digunakan dalam penelitian adalah kualitatif deskriptif. Subjek penelitian adalah siswa kelas XI ATPH SMK Negeri 1 Woja tahun ajaran 2018/2019. Data yang digunakan hasil hasil tes, dan wawancara. Hasil penelitian menunjukan bahwa menunjukan bahwa aktivitas curah pendapat dapat meningkatkan keterampilan siswa di dalam menggunakan bahasa Inggris lisan yang berterima khususnya untuk mengungkapkan monolog descriptive. Terbukti dari analisis data secara kuantitatif menunjukkan bahwa nilai hasil belajar siswa pada umumnya diatas Kriteria Ketuntasan Minimal (KKM) bahasa Inggris yaitu 70 .
\end{abstract}

Keywords: Constructivists, Models, Cycles, Activities.

Kata kunci : Konstruktivis, Model, Siklus, Aktivitas.

\footnotetext{
${ }^{1}$ Penulis adalah guru Bahasa Inggris di SMK Negeri 1 Woja 


\section{A. Latar Belakang}

Dalam undang-undang republik indonesia no 20 tahun 2003 tentang pendidikan nasional pasal 1 ayat (1) dinyatakan bahwa pendidikan dasar dan terencana untuk mewujudkan suasana belajar dan proses pembelajarann agar perserta didik secara aktif mengembangkan potensi dirinya untuk memiliki kekuatan spiritual keagamaan, pengendalian diri, kepribadian, kecerdasan, akhlak mulia, serta keterampilan yang diperlukan dirinya, masyarakat, bangsa dan Negara, (Muhibbin, 2007 : 12). Untuk mendapatkan manusia yang berkualitas dibutuhkan proses pendididkan yang berkualitas pula.untuk itu salah satu upaya pemerintah meningkatkan mutu pendidikan sekolah ialah dengan cara memperbaiki proses belajar mengajar.

Tercapainya tujuan pembelajaran merupakan harapan utama dalam setiap pelaksanaan proses belajar mengajar. Kemampuan guru dalam mengelola dan mengembangkan pendekatan pembelajaran merupakan salah satu faktor yang erat kaitanya dengan upaya pencapaian tujuan pembelajaran. Pada umumnya guru melaksanakan pembelajaran yang bersifat monoton, kurang berkembang, kurang kreatif dan lebih dominan menggunakan metode ceramah, sehingga membosankan bagi siswa. Sudah saatnya guru merubah paradigma lama tentang proses pembelajaran yang lebih dominan pada keaktifitas guru.

Pembelajaran pada hakekatnya adalah proses interaksi antara peserta didik dengan lingkungannya, sehingga terjadi perubahan perilaku kearah yang lebih baik. Dalam interaksi tersebut banyak sekali dalam diri Individu, maupun faktor eksternal yang datang dari lingkungan (Mulyasa, 2008 : 100).

\section{B. Landasan Teori}

\section{Pembelajaran Konstruktivis}

Belajar bukan menghafal dan bukan pula mengingat. Belajar adalah suatu proses yang ditandai dengan adanya perubahan pada diri seseorang. Perubahan sebagai hasil proses belajar dapat ditunjukan dalam berbagai bentuk seperti perubahan pengetahuan, pemahannya, sikap dan tingkah lakunnya, keterampilannya, kecakapan, dan kemampuannya, daya reaksinya, daya penerimaannya dan lain-lain aspek yang ada pada individu (Sudjana, $2008: 25$ )

Hamalik (2003 : 57) menyatakan bahwa pembelajaran adalah suatu kombinasi yang tersusun atas unsur-unsur manusiawi, material, fasilitas, perlengkapan dan prosedur yang saling mempengaruhi untuk mencapai pembelajaran. Unsur manusiawi maksudnya adalah manusia yang terlibat dalam sestem pengajaran terdiri dari siswa, guru dan tenaga dan tenaga laboraturuim. Material, meliputi buku-buku, papan tulis, kapur, film, audio dan video tipe. Fasilitas dan perlengkapan audiovisual, juga kompeter. Prosedur, meliputi jadwal dan metode penyampaian informasi, praktik belajar ujian dan lain-lain.

Menurut teori konstruktivisme, bejalar tidak sekedar menghafal. Agar siswa benar-benar memahami dan dapat menerapkan pengetahuan yang memperolehnya maka siswa perlu dibiasakan untuk memecahkan masalah, menentukan sesuatu yang berguna bagi dirinya 
dan bergelut dengan ide-ide. Selanjutnya di dalam belajar siswa harus aktif menemukan dan menerapkan informasi kompleks, mengecek informasi baru, membandingkan dengan aturan lama dan memperbaiki aturan itu apabila tidak sesuai lagi. Perubahan kognitif terjadi apabila konsep-konsep sebelumnya tidak sesuai saat dikaitkan dengan informasi (Dirpendasmen, 2002 : 56).

Keberhasilan belajar menurut pandangan konstruktivisme bergantung bukan hanya pada lingkungan atau kondisi belajar, tetapi juga pada pengetahuan awal siswa. Belajar melibatkan pembentukan "makna" oleh siswa. Dari apa yang mereka lakukan, lihat dan dengar. West dan pines (dalam Sutarno, 2003 : 95).

Dari beberapa pandangan di atas dapat disimpulkan bahwa pembelajaran yang mengacu kepada teori belajar konstruktivisme lebih terfokus pada kesuksesan siswa dalam mengorganisasikan pengalaman mereka dan bukan pula keputusan siswa dalam refleksi atas apa yang telah diperintahkan dan dilakukan oleh guru. Dengan kata lain, siswa lebih diutamakan untuk mengkonstruksi sendiri pengetahuan mereka melalui asimilasi dan akomodasi.

Praktik pembelajaran konstruktivis menuntut guru agar menjadikan siswa pusat pembelajaran. Siswa diharapkan lebih banyak bertanya dan pertanyaan siswa harus dijadikan dasar pembahasan, peneyelidikan dan kegiatan dalam kelas atau laboratorium. Siswa diharapkan menyarankan pemecahan masalah dan menawarkan penjelasan ini harus digunakan dalam kelas sebagai dasar untuk mencari informasi lain dan untuk diuji ketepatannya. Hal ini menyarankan adanya keterlibatan yang dimulai dari siswa, beranjak ke pasangan siswa atau ke diskusi kelompok kecil untuk membahas pertanyaan-pertanyaan lebih lanjut dan mencari konsensus, kemudian ke diskusi kelas dan berakhir dengan bagaimana pendapat pakar ilmunya (Anonim, 2008).

Menurut Sutarno (2003 : 63) dikenal beberapa model pembelajaran yang dilandasi konstruktivisme yaitu model silkus pelajar (learning cycle model), model pembelajaran generatif (generative learning model), model pembelajaran interaktif (interactive learning model ), model CLIS (Children learning In science). Masing-masing model memiliki kekhasan tersendiri, tetapi semuanya mengembangkan kemampuan struktur kognitif untuk membangun pengetahuan sendiri melalui berpikir rasional. Kekhasan model-model tersebut tampak pada tahapan (fase) kegiatan pembelajaran yang dilakukan. Perbandingan fase-fase dari model-model tersebut dirangkum pada Tabel 2.1

Tabel 2.1. Fase-fase Pembelajaran pada Kelompok Model Pembelajaran Konstruktivis

\begin{tabular}{cccccc}
\hline \multirow{2}{*}{ Model } & \multicolumn{5}{c}{ Fase-fase pembelajaran } \\
\cline { 2 - 6 } & I & II & III & IV & V \\
\hline $\begin{array}{c}\text { Siklus } \\
\text { Belajaran }\end{array}$ & Eksplorasi & $\begin{array}{c}\text { Pengenala } \\
\text { n Konsep }\end{array}$ & $\begin{array}{c}\text { Penerapan } \\
\text { konsep }\end{array}$ & - & - \\
\hline Pembelajaran & Persiapan & Fokus & Tantangan & Aplikasi & - \\
\hline
\end{tabular}




\begin{tabular}{cccccc}
\hline Generatif & & & & & \\
\hline $\begin{array}{c}\text { Pembelajaran } \\
\text { Interaktif }\end{array}$ & Persiapan & Eksplorasi & $\begin{array}{c}\text { Pertanyaan } \\
\text { Siswa }\end{array}$ & Refleksi & - \\
\hline CLIS & Orientasi & Elisitasi & Restrukturisasi & Aplikasi & Refleksi \\
\hline $\begin{array}{c}\text { Pembelajaran } \\
\text { Kooperatif }\end{array}$ & Orientasi & Elisitasi & Restrukturisasi & Aplikasi & Refleksi \\
\hline
\end{tabular}

Sumber : Sutarno (2003: 120)

\section{Model Siklus Belajar}

Urutan pembelajaran model siklus belajar yaitu : pertama tahap eksplorasi, pada tahap ini siswa kesepakatan untuk melakukan penjelajahan atau eskplorasi secara bebas. Kegiatan ini memberikan siswa pengalaman fisik dan interaksi sosial dengan teman dan gurunya. Pengalamn ini mendorong terjadinya asimilasi dan menyebabkan siswa bertanya tentang konsep tertentu yang tidak sesuai dengan konsepsi awal mereka. Kedua adalah tahap pengenalan konsep, pada pengenalan konsep, guru dengan metode yang sesuai menjelaskan konsep dan teoriteori yansg dapat membantu siswa untuk menjawab permasalah yang muncul dan menyusun gagasan mereka. Tahap ketiga yaitu penerapan konsep, siswa mencoba menggunakan konsep yang telah dikuasi untuk memecahkan masalah dalam situasi yang berbeda. Dalam hal ini guru menyiapkan masalah-masalah yang dapat dipecahkan berdasarkan konsep yang telah diperoleh siswa pada fase sebelumnya (Sutarno, 2003 : 31).

Menurut Dasna 2005 dalam Fibrianti (2007 : 90) ada 5 fase ini dalam siklus belajar yaitu :

1. Fase pendahuluan (engagement), kegiatan pada fase ini bertujuan untuk mendapatkan perhatikan siswa, mendorong kemampuan berpikir, dan membantu siswa mengakses pengetahuan awal yang telah dimiliki.

2. Fase eksplorasi (exploration), kegiatan fase ini siswa diberi kesempakatan untuk bekerja, baik secara mandiri maurun secara kelompok tanpa instruksi langsung dari guru.

3. Fase penjelasan (explanation), kegiatan pada fase ini bertujuan untuk melengkapi atau menyempurnakan dan mengembangkan konsep yang diperoleh siswa. Guru akan menjelaskan konsep yang dipahaminya dengan kata-katanya sendiri, menunjukkan contoh nyang berhubungan dengan konsep untuk melengkapi penjelaskannya, serta bisa memperkenalkan istilah-istilah baru yang belum diketahui siswa.

4. Fase penerapan konsep (elaboration), kegiatan fase ini mengarahkan siswa penerapan konsep-konsep yang telah dipahami dan keterampilan yang miliki pada situasi. Fase ini bertujuan untuk meningkatkan pemahaman siswa tentang apa yang telah mereka ketahui. 
5. Fase evaluasi (evaluation), kegiatan pada fase ini ada dua hal yang ingin diketahui yaitu pengalaman belajar yang telah telah diperoleh siswa dan refleksi untuk melakukan siklus lebih lanjut.

Menurut Karplus dalam Indrawati (2000 : 74) model siklus belajar terdiri dari 3 fase yaitu eksplorasi, pengenalan konsep dan aplikasi konsep. Pada fase eksplorasi, siswa secara langsung diberi kesempatan menggunakan pengetahuan awalnya dalam mengobservasi, memahami fenomena alam dan mengkomunikasikannya dengan orang lain. Pada fase pengenalan konsep, guru mengontrol langsung pengembangan konsep yang dilakukan siswa dan membantu dalam mengidentifikasikan konsep serta menghubungkan antara konsep yang telah dapat dan pada fase aplikasi konsep, siswa melakukan kegiatan penerapan konsep IPA dalam kontek kehidupan sehari-hari dan selanjutnya menerapkan konsep pada situasi baru.

Ada 4 fase dalam pembelajaran dengan model siklus belajar yaitu:

1) Fase eskplorasi, fase ini berpusat pada siswa, menstimulasi ketidak keseimbangan mental pembelajaran dan menggalakkan asimilasi mental.

2) Fase eskplanasi (penjelasan), pada fase ini kurang pada siswa dan memberikan kesempatan untuk akomodasi mental pembelajaran.

3) Fase ekspansi (pengembangan), fase ini sedapat mungkin berpusat pada siswa diorganisasikan untuk memberikan semangat kerja kelompok.

4) Fase evaluasi, tujuan fase ini adalah mengatasi keterbatasan dari penilaian tipe-tipe baku. (Anonim, 2008 : 133)

\section{Aktivitas Belajar}

Dalam diri masing-masing siswa terdapat "prinsip aktif " yakni keinginan berbuatan dan bekerja sendiri. Sehubungan dengan hal tersebut. Sistem pembelajaran dewasa ini sangat menekankan pada pendayagunaan asas aktivitas (keaktifan) dalam proses belajar dan pembelajaran untuk mencapai tujuan yang telah ditentukan.

Aktivitas belajar menurut Hamalik (2002 : 170) adalah suatu proses atau kegiatan yang dilakuakan untuk mencapai mengetahuan. Keterampilan, nilai dan sikap. Oleh karena itu, guru yang bertindak sebagai fasilitator dan mediator dalam pembelajaran hendaknya mampu menciptakan pembelajaran yang terdapat mengikut serta siswa aktif baik individu maupun kelompok dalam kegiatan pembelajaran.

Menurut Djamarah, (2008 : 33) ada beberapa aktivitas belajar yaitu sebagai berikut :

1. Mendengarkan, adalah salah satu aktivitas belajar. Setiap orang yang belajar di sekolah pasti aktifitasnya mendengarkan ketika seorang guru menggunakan metode ceramah maka setiap siswa harus mendengar apa yang pendidik sampaikan 
2. Memandang, adalah mengarahkan penglihatan ke suatu objek. Aktivitas memandang dalam arti belajar adalah aktivitas memandang yang bertujuan sesuai dengan kebutuhan untuk mengadakan perubahan tingkah laku yang positif.

3. Meraba, membau, dan mencincipi atau mengecap adalah indera manusia dapat dijadikan sebagai alat untuk kepentingan belajar. Artinya aktivitas meraba, membau, mengecap dapat memberikan kesempakatan bagi seseorang untuk belajar.

4. Menulis dan mencatat, merupakan kegiatan yang tidak dapat dipisahkan dari aktivitas belajar. Mencacat yang termasuk sebagai aktivitas belajar adalah apabila mencatat itu orang menyadari kebutuhannya dan tujuannya serta menggunakan seperangkat tertentu akar catatan itu nantinya berguna bagi pencapaian belajar.

5. Menbaca adalah aktivitas yang banyak dilakukan disekolah dan keperguruan tinggi. Membaca disini tidak mesti membaca buku belaka, tetapi juga membaca majalah, koran, tabloid, jurnal-jurnal hasil penenilitian, catatan hasil belajar, atau kuliah dan hal-hal lainnya yang berhungan dengan kebutuhan studi.

6. Membuat ikhtisar atau ringkasan atau menggaris bawahi, dapat membantu dalam hal mengingat atau mencari kembali materi dalam buku untuk masa-masa akan datang.

7. Mengamati tabel-tabel, diagram-diagram, dan bagan-bagan merupakan suatu yang sangat perlu bagi seseorang dalam mempelajari materi yang relavan. Demikian pula gambar-gambar, peta-peta, dan lain-lain dan dapat menjadi bahan ilustratif yang membantu pemahaman seseorang tentang sesuatu hal.

8. Menyusun paper atau kertas kerja, dalam menyusun paper harus sistimatik dan metodelogis, arti menggunakan metode-metode tertentu dalam penggarakannya. Sistimatik artinya menggunakan kerangka berpikir yang logis dalam kronologis.

9. Mengingat, adalah gejala psikologi. Ingatan itu sendiri adalah kemampuan jiwa untuk memasukan (learning), menyimpan (reiention), dan menimbulkan kembali (remembering) hal-hal yang telah lampau. Jadi menjadi mengenalkan itu sendiri ada 3 yaitu memasukan, menyimpang dan menyangkat kealam sadar.

10. Berpikir adalah termasuk aktivitas belajar. Dengan berpikir orang memperoleh penemuan baru, setidaknya orang menjadi tahu tentang hubungan antara suatu.

11. Latihan atau praktik, adalah konsep belajar yang menghendaki adanya penyatuan usaha mendapatkan pesan dengan cara membuat. Dalam hal ini belajar sambil berbuat adalah termasuk latihan.

Adapun penggunaan asas aktivitas belajar dalam pembelajaran seperti yang diungkapkan oleh Hamalik (2002 : 85) antara lain : (1). Para siswa mencari pengalaman sendiri dan langsung mengalami sendiri. (2). Membuat sendiri akan mengembangkan seluruh aspek 
pribadi siswa secara integral. (3). Memupuk kerjasama yang harmonis dikalangan siswa.(4). Para siswa bekerja menurut minat dan kemampuan sendiri. (5). Memupuk disiplin kelas secara wajar dan suasana belajar menjadi demokratis. (6). Mempererat hubungan sekolah dan masyarakat, dan hubungan antar orang tua dengan guru. (7). Pengajaran diselenggarakan secara realities dan konkret sehingga mengembangkan pemahaman dan berpikir kritis serta menghindari verbalistik. (8). Pengajaran disekolah menjadi hidup sebagaimana aktivitas dalam kehidupan dimasyarakat.

\section{Kriteria Ketuntasan Minimal (KKM)}

Kriteria Ketuntasan Minimal (KKM) adalah batas nilai minimal yang harus dicapai oleh peserta didik pada setiap mata pelajaran baik sebagian (pokok bahasan). Maupun secara keseluruhan dalam rentang semester. KKM ditentukan oleh sekolah pada awal tahun ajaran sehingga dapat dijadikan cerminan tingkat kualitas pendidikan yang akan dicapai dan di syaratkan pada satuan pendidikan (sekolah) bersangkutan (Sidik, 2008).

Kriteria tuntas yang ditetapkan dan berlaku dalam petunjuk teknis pembelajaran bahasa Inggris disebutkan bahwa dinyatakan tuntas belajar secara individu apabila mencapai nilai $\geq 70$, sedangkan untuk klasikal dinyatakan tuntas belajar $85 \%$ siswa telah mencapaia $\geq 70$ (Sidik, 2008).

Adapaun fungsi Kriteria Ketuntasan Minimal (KKM) yaitu : (1). Sebagai acuan bagi pendidik dalam menilai kompentensi perserta didik sesuai kompentensi dasar mata pelajaran yang mengikuti. Setiap kompetensi dasar dapat diketahui ketercapaiannya berdasarkan KKM. (2). Sebagai acuan bagi perserta didik dalam menyiapkan diri mengikuti penilaian mata pelajaran. (3). Dapat digunakan sebagai bagian dari komponen dalam melakukan evaluasi program pembelajaran yang dilakuakn di sekolah. (4). Merupakan target satuan pendidikan dalam penyampaian kopetensi setiap mata pelajaran (Sidik 2008).

Untuk mengetahui ketuntasan belajar siswa yaitu dengan melihat kriteria ketuntasan minimal (KKM) dan hasil belajar siswa. Kreteria Ketuntasan Minimal (KKM) merupakan tingkat pencapaian kompetensi dasar yang harus dicapai oleh siswa per mata pelajaran yang ditetapkan oleh guru dengan mempertinbangkan ketuntasan belajar ideal untuk setiap indikator adalah 0-100\% dengan batas kriteria ideal minimal $75 \%$, kemampuan rata-rata peserta didik, kompleksitas dan sumber daya manusia. Dimana ketentuan dalam ketuntasan belajar, siswa yang belum tuntas harus ikut program remedial (Depdiknas, 2006 : 18).

\section{Hasil dan Pembahasan}

\section{Hasil Penelitian}

Penelitian ini telah dilaksanakan pada Tanggal 10 maret sampai dengan Tangal 01 april 2019 pada kelas XI ATPH SMK Negeri 1 Woja

$$
\text { 61|Edisi } 2 \text { No.1 Januari } 2020
$$


Kabupaten Dompu. Dari hasil penelitian ini diperoleh data kuantitatif dan kualitatif. Data kualitatif yaitu data tentang hasil observasi aktivitas siswa selama proses pembelajaran berlangsung, sedangkan kuantitatif merupakan data tentang tes hasil belajar dan prestasi belajar siswa secara klasikal. Penelitan tindakan ini dilakukan sebanyak tiga siklus terdiri dari satu kali pertemuan. Perincian hasil penelitian yang diperoleh dapat diuraikan sebagai berikut :

\section{a. Data Hasil Observasi Keterlaksanaan Pembelajaran}

Hasil observasi keterlaksanaan pembelajaran dari siklus I sampai siklus III secara ringkas dapat dilihat dalam Tabel 1 .

Tabel 1. Persentase Keterlaksanan Pembelajaran

\begin{tabular}{|c|c|c|c|c|}
\hline \multirow{2}{*}{$\%$ keterlaksnaan } & RPP-01 & RPP-02 & RPP- 03 & Rata-rata \\
\cline { 2 - 5 } & $78,57 \%$ & $85,71 \%$ & $100 \%$ & $88 \%$ \\
\hline
\end{tabular}

Pada Tabel 1. Terlihat rata-rata keterlaksanaan pembelajaran dari 3 Rencana Pelaksanaan Pembelajaran (RPP). Pada siklus I memiliki rata-rata $78,57 \%$ hal ini disebabkan karena masih ada skenario pembelajaran yang belum dilaksanakan oleh guru, kemudian pada siklus II meningkat menjadi 85,71 \%. Meskipun terlihat adanya peningkatan pada siklus II tetapi masih ada skenario pembelajaran yang masih belum terlaksana sehingga pembelajara dilanjutkan pada siklus III, pada siklus III dilakukan penyempurnaan terhadap skenario pembelajaran yang belum terlaksana pelaksanaan tindakan pada siklus III mengalami peningkatan yang signifikasi yaitu $100 \%$.

b. Data Aktivitas Balajar Siswa

Tabel 2. Analisis Hasil Aktivitas Siswa Selama Proses Pembelajaran Siswa Kelas XI ATPH SMK Negeri 1 Woja Tahun Pelajaran 2018/2019

\begin{tabular}{ccccc}
\hline Siklus & J umlah siswa & Nilai total & $\begin{array}{c}\text { Rata- } \\
\text { rata }\end{array}$ & Kategori \\
\hline I & 35 & 769 & $21,9 \%$ & C. Aktif \\
\hline II & 35 & 820 & $23,4 \%$ & C. Aktif \\
\hline III & 35 & 887 & $25,34 \%$ & Aktif \\
\hline
\end{tabular}

Berdasarkan Tabel 2. di atas, bahwa selisih nilai rata-rata keaktivan siswa mengalami peningkatan. Pada siklus I memiliki ratarata $21,9 \%$ dengan kategori cukup aktif, kemudian pada siklus II rata-ratanya $23,4 \%$ dengan kategori cukup aktif mengalami peningkatan sebesar $1,55 \%$ dan pada siklus III meningkat menjadi $25,34 \%$ dengan kategori aktif.

\section{c. Data Hasil Belajar}

Setelah dilaksanakan proses belajar mengajar pada tiap siklusnya siswa akan diberikan tes. Tes dilaksanakan pada tiap akhir proses belajar mengajar berlangsung, dengan tujuan untuk mengukur atau mengetahui sejauh mana siswa menguasai materi yang telah 
diberikan oleh guru dan untuk mengetahui peningkatan prestasi belajar siswa pada setiap siklusnya.

Tabel 3. Analisis hasil belajar siswa kelas XI ATPH SMK Negeri 1 Woja Tahun Pelajaran 2018/2019

\begin{tabular}{cccc}
\hline Siklus & $\begin{array}{c}\text { Jumlah } \\
\text { siswa }\end{array}$ & $\begin{array}{c}\text { Jumlah siswa yang } \\
\text { mendapat nilai } \geq \mathbf{7 0}\end{array}$ & $\begin{array}{c}\text { persentase(\% ) } \\
\text { ketuntasan }\end{array}$ \\
\hline I & 35 & 15 & $42,85 \%$ \\
\hline II & 35 & 20 & $57.14 \%$ \\
\hline III & 35 & 34 & $97,14 \%$ \\
\hline
\end{tabular}

Tabel 3. di atas terlihat bahwa hasil belajar siswa dari siklus ke sikus mengalami peningkatan. Pada siklus I jumlah siswa yang memperoleh nilai $\geq 70$ adalah 15 orang dan persentasenya adalah $42,85 \%$ dengan kategori tidak tuntas, kemudian pada siklus II persentasenya $57,85 \%$ dengan kategori tidak tuntas terlihat bahwa pada siklus II mengalami peningkatan. Kemudian pada siklus III persentasenya 97, $14 \%$ dengan kategori tuntas, pada siklus III juga mengalami peningkatan.

\section{Pembahasan}

\section{a. Keterlaksanaan Pembelajaran}

Persentase keterlaksanaan pembelajaran dengan menggunakan metode pembelajaran konstruktivis dengan model siklus belajar dari tiap siklusnya menngalami peningkatan (Lihat Tabel 1). pada siklus I belum mengalami peningkatan karena masih ada beberapa skenario pembelajaran yang masih belum terlaksana diantaranya :

a. Dalam membuka pelajaran guru kurang memperhatikan kesiapan siswa

b. Waktu yang disediakan tidak cukup untuk melakukan diskusi

c. Guru kurang membimbing siswa dalam mengerjakan LKS

d. Guru tidak maksimal mengarahkan siswa dalam membuat kesimpulan

e. Guru kurang memberikan umpan balik terhadap materi pelajaran.

Menurut Nunung (2008) umpan balik dalam proses belajar mengajar sangat penting, supaya siswa mengetahui benar tidaknya pekerjaan yang siswa lakukan. Umpan balik dari guru, sebaiknya yang mampu menyadari siswa terhadap kesalahan mereka dan meningkatkan pemahaman siswa akan pelajaran tersebut.

Pada siklus II mengalami peningkatan, hal tersebut dikarenakan peneliti sudah melakukan perbaikan pada siklus sebelumnya diantaranya : guru telah mampu membimbing siswa dalam melakukan diskusi, guru sudah mampu mengatur waktu yang telah disediakan sehingga proses belajar mengajar dapat berjalan dengan lancar, dan guru juga sudah memberikan penguatan atas jawaban siswa sehingga siswa termotivasi untuk melakukan proses belajar mengajar.

Meskipun pada siklus II mengalami peningkatan tetapi masih terdapat kekurangan diantaranya : guru belum maksimal mengarahkan siswa

$$
\text { 63| Edisi } 2 \text { No.1 Januari } 2020
$$


dalam membuat kesimpulan dan guru kurang smemberikan umpan balik terhadap materi yang disampaikan sehingga proses belajar mengajar pada siklus II masih harus diperbaiki pada siklus selanjutnya. Pada siklus III pelaksanaan skenario pembelajaran semakin baik dan proses belajar mengajar berjalan lancar serta siswa sudah terlihat antusias dalam proses belajarnya. Sseluruh skenario pembelajaran sudah terlaksana dan siklus diakhiri.

\section{b. Aktivitas Belajar Siswa}

Aktivitas belajar adalah suatu proses atau kegiatan yang dilakukan untuk mencapai pengetahuan, keterampilan, nilai dan sikap. Oleh karena itu, guru yang bertindak sebagai fasilitator dan mediator dalam pembelajaran hendaknya mampu menciptakan pembelajaran yang dapat mengikutsertakan siswa secara aktif baik individu maupun kelompok dalam kegiatan pembelajaran.

Persentase aktivitas siswa dengan menggunakan pembelajaran konstuktivis dengan model siklus belajar pada tiap siklusnya mengalami peningkatan. Pada siklus I belum mengalami peningkatan, hal ini disebabkan karena siswa masih kurang aktif dalam melaksanakan kegiatan mengajar karena siswa cenderung melakukan pekerjaan yang lain pada saat pembelajaran berlangsung. Hal ini juga terkait dengan interaksi antara guru dengan siswa yang belum maksimal serta kurangnya umpan balik dari guru. Kemudian pada siklus II persentase aktivitas siswa meningkat, meskipun mengalami peningkatan tetapi masih ada sebagian siswa yang cenderung melakukan kegiatan yang lain misalnya berbicara dengan teman sebangkunya pada saat proses belajar mengajar.

Pada siklus III juga mengalami peningkatan yaitu sudah mencapai kategori aktif, hal ini dikarenakan siswa sudah melakukan proses belajar mengajar dengan baik. Oleh karena itu berdasarkan hal-hal di atas dapat diketahui bahwa pembelajaran konstruktivis dengan model siklus belajar dapat meningkatkan aktivitas belajar siswa.

\section{c. Hasil Belajar}

Dari hasil pembelajaran siklus I sampai siklus III mengalami peningkatan. Pada siklus I terlihat masih belum tuntas. Hal ini disebabkan karena guru kurang menguasai kelas, kurangnya interaksi antara guru dengan siswa sehingga siswa tidak termotivasi untuk belajar. Kekurangan pada siklus I dilakukan per baikan pada siklus berikutnya dengan memberikan motivasi pada siswa agar siswa terlibat aktif dalam proses kegiatan belajar mengajar terutama siswa yang nilainya $\leq 70$

Setelah dilakukan perbaikan pada siklus II, maka persentase ketuntasan belajar siswa meninkatkan, akan tetapi ketuntasan belajar secara klasikal belum tercapai. Hal ini terkait dengan kurangnya umpan balik dari guru, dan kurang membimbing siswa dalam mengerjakan LKS.

Serangkaian kegiatan dalam proses belajar mengajar telah di lalui dari siklus berikutnya, berdasarkan pada pengalaman dan kelemahan yang ada pada siklus I dan II maka usaha perbaikan dan pencapaian

$$
\text { 64| Edisi } 2 \text { No.1 Januari } 2020
$$


proses belajar mengajar diperoleh lebih baik. Karena dengan perbaikan proses pembelajaran yang dilakukan peneliti secara terus menerus tiap siklusnya maka akan mempegaruhi keterlaksanaan RPP dan pada akhirnya mempegaruhi pula terhadap hasil belajar siswa.

Dilihat dari nilai rata-rata dari siklus I, siklus II sampaisiklus III menunjukkan bahwa dengan pembelajaran konstruktivis dengan model siklus belajar dapat meningkatkan preestasi belajar bahasa Inggris pada pokok bahasan keanekaragaman hayati pada siswa kelas XI ATPH SMK Negeri 1 Woja Tahun Pelajaran 2018/2019.

\section{Simpulan}

Berdasarkan hasil analisis data dapat disimpulkan bahwa Pembelajaran Konstruktivis Dengan Model Siklus Belajar dapat meningkatkan hasil belajar bahasa Inggris siswa kelas XI ATPH SMK Negeri 1 Woja Tahun Pelajaran 2018/2019

1. Data Hasil Observasi Keterlaksanaan Pembelajaran

Keterlaksanan pembelajaran dari 3 Rencana Pelaksanaan Pembelajaran (RPP). Pada siklus I memiliki rata-rata 78,57 \%. Hal ini disebabkan karena masih ada skenario pembelajaran yang belum dilaksanakan oleh guru, kemudian pada siklus II meningkat menjadi 85, $71 \%$. Meskipun melihat peningkatan pada siklus II tetapi masih ada skenario pembelajaran yang masih belum terlaksana sehingga pembelajaran dilanjutkan pada siklus III, pada siklus III dilakukan penyempurnaan terhadap skenario pembelajaran yang belum terlaksana pelaksanaan tindakan pada siklus III mengalami peningkatan yang signifikasi yaitu $100 \%$.

2. Data Aktivitas belajar Siswa

Selisih nilai rata-rata keaktivan siswa mengalami peningkatan. Pada siklus I memiliki rata-rata 21,9\% dengan kategori cukup aktif. Kemudian pada siklus II rata-ratanya $23,4 \%$ dengan kategori cukup aktif mengalami peningkatan sebesar $1,55 \%$ dan pada siklus III meningkat menjadi $25,34 \%$ dengan kategori aktif.

3. Data Hasil Belajar

Hasil belajar siswa dari siklus ke sikus mengalami peningkatan. Pada siklus I jumlah siswa yang memperoleh nilai $\geq 70$ adalah 15 orang dan persentasenya adalah 42,85 \% dengan kategori tidak tuntas. Kemudian pada siklus II persentasenya 57,85 \% dengan kategori tidak tuntas terlihat bahwa pada siklus II mengalami peningkatan. Kemudian pada siklus III persentasenya 97, $14 \%$ dengan kategori tuntas, pada siklus III juga mengalami peningkatan. 


\section{Daftar Rujukan}

Arikunto, S., 2006. Prosedur Penelitian Tindakan Satuan Pendekatan Praktek. Jakarta : Rineka Cipta , 2007. Peneltian Tindakan Kelas. Jakarta : Bumi Aksara. 2008. Pembelajaran Sains Dengan Pendekatan STM. RUT VI Kantor Menteri Riset Nasional.

Dasna, 2005. Pembelajaran Dengan Siklus Belajar.

Djamarah, S. B. 2008. Psikologi Belajar. Jakarta : Rineka Cipta.

Hamalik, O. 2003. Kurikulum Dan Pembelajaran. Jakarta : Bumi Aksara. . 2002. Proses Belajar Mengajar. J akarta : PT. Bumi Aksara.

Indrawati. 2000. Model-model Pembelajaran IPA. Bandung: PPPG IPA.

Margono, S. 2009. Metodelogi Penelitian Pendidikan. Jakarta : Rineka Cipta

Muhibbin, Syach. 2007. Psikologi Pendidikan Dengan Pendekatan Baru Bandung: PT. Remaja Rosdakarya.

Mulyasa, E. 2008. Kurikulum Berbasis Kompetensi. Bandung : Remaja Rosdakarya.

Nazir, M. 2003. Metode Penelitian. Jakarta: Galia Indonesia.

Nunung, 2008. Pengaruh Alternatif Hiburan Terhadap Minat Belajar Siswa Kelas VII SMPN 1 Mataram Tahun Ajaran 2008/2009. Mataram : IKIP Mataram

Ridwan, 2004. Belajar mudah untuk Guru - Karya dan Peneliti Pemula. Bandung: Alfabeta

Sidik, P. 2008. Kriteria Ketuntasan Minimal. Http:// Sidik. Net/ KriteriKetuntasan-Minimal-KKM. Karya IImiah Diakses 12 Desember 2009.

Sutarno, N. 2003. Materi Dan Pembelajaran IPA SD. Universitas Terbuka J akarta: Depdiknas.

Sudjana, N. 2008. Dasar-dasar Proses Belajar mengajar. Bandung : Sinar baru Algesindo 